\title{
Cephaleuros virescens, the cause of an algal leaf spot on Para rubber in Thailand
}

\author{
Mutiara K. Pitaloka • Vasun Petcharat • Siwaret Arikit • \\ Anurag Sunpapao
}

Received: 15 July 2014 / Accepted: 4 January 2015 / Published online: 30 January 2015

(C) Australasian Plant Pathology Society Inc. 2015

\begin{abstract}
In this study Cephaleuros virescens was found to be the causal organism of a leaf spot disease on Para rubber (Hevea brasiliensis). The algae caused circular orange to dark brown lesions on both leaf surfaces. The morphology of the algae (thallus, filamentous cells, sporangiophore, sporangia, gametangia and zoospore) were examined and found to consistently match the species Cephaleuros virescens.
\end{abstract}

Keywords Algae Cephaleuros · Hevea brasiliensis · Leaf spot · Morphology

Para rubber (Hevea brasiliensis) is a tree belonging to the family Euphorbiaceae. It is commonly cultivated in tropical and sub-tropical areas and is an economically important source of natural latex rubber. Para rubber trees need long periods of high rainfall to produce a high yield of latex and are therefore cultivated in southern Thailand where suitable weather occurs. Like other plants, Para rubber is attacked by several pathogens and one of the most frequently found is a leaf spot caused by a phytoparasitic algae.

M. K. Pitaloka $\cdot$ V. Petcharat $\cdot$ A. Sunpapao $(\bowtie)$

Department of Pest Management, Faculty of Natural Resources, Prince of Songkla University, Hatyai, Songkhla 90112, Thailand

e-mail: anurag.su@psu.ac.th

S. Arikit

Rice Science Center and Department of Agronomy at Kamphaeng Saen, Faculty of Agriculture, Kasetsart University, Kamphaeng Saen Campus, Nakhon Pathom 73140, Thailand
Green algae in the genus Cephaleuros are known to be parasitic on several woody plants. Signs of the disease are often found on the leaf surface in the form of burnt-orange to brown spots (Nelson 2008). Leaf tissues are colonized beneath the epidermis by algal filaments, but host cells are not penetrated (Chapman and Henk 1985). Stems and fruits may also be infected. Cephaleuros spp. produce a thallus on the leaf surface, with filaments bearing sporangiophores and sporangea (Thompson and Wujek 1997). Cephaleuros spp. predominantly occur in tropical and subtropical regions. Recently, Cephaleuros solutus was reported causing a leaf spot on durian in Thailand (Pitaloka et al. 2014). The record of Cephaleuros solutus on durian was the first record of Cephaleuros sp. causing disease in Thailand. The purpose of our study was to identify and characterize Cephaleuros species present on Para rubber in Thailand.

Fifteen specimens of algal leaf spot from Para rubber leaves were collected from Songkhla, Trang and Phattalung provinces, southern Thailand. Algal thalii were selected from fresh leaves and initially observed under a stereomicroscope. The symptoms on leaf tissues were then photographed. Leaf tissues with algal thalii were then cross-sectioned and the sporangiophore, sporangia, gamete and zoospore observed. Morphological characteristics of the Cephaleuros spp. on Para rubber were compared to descriptions described in the monograph by Thompson and Wujek (1997).

Based on the leaf symptom and morphological characteristics of the algae as described in Fig. 1, and comparison in Table 1, 15 alga samples were identified as 
Fig. 1 a) Leaf spot on Hevea braziliensis leaf, $b$ ) lesion caused by Cephaleuros on upper leaf, $c$ ) lesion on lower leaf surface, $d$ ) young thallus on upper leaf surface with sporangiophores, $e$ ) thallus with gametangia $(\mathrm{G})$ and setae (Se), $f$ )

pseudoparenchymatous thalli of C. virescens, $g$ ) sporangiophores (SP) with the head cell (HC) and suffultory cell (SC) bearing sporangia (S) on the top, $h$ ) transverse section of leaf tissue show subcuticular and subepidermal growth of the thallus, cuticle (cu), epidermis (ep), palisade cells (ps) and $i$ ) gametes

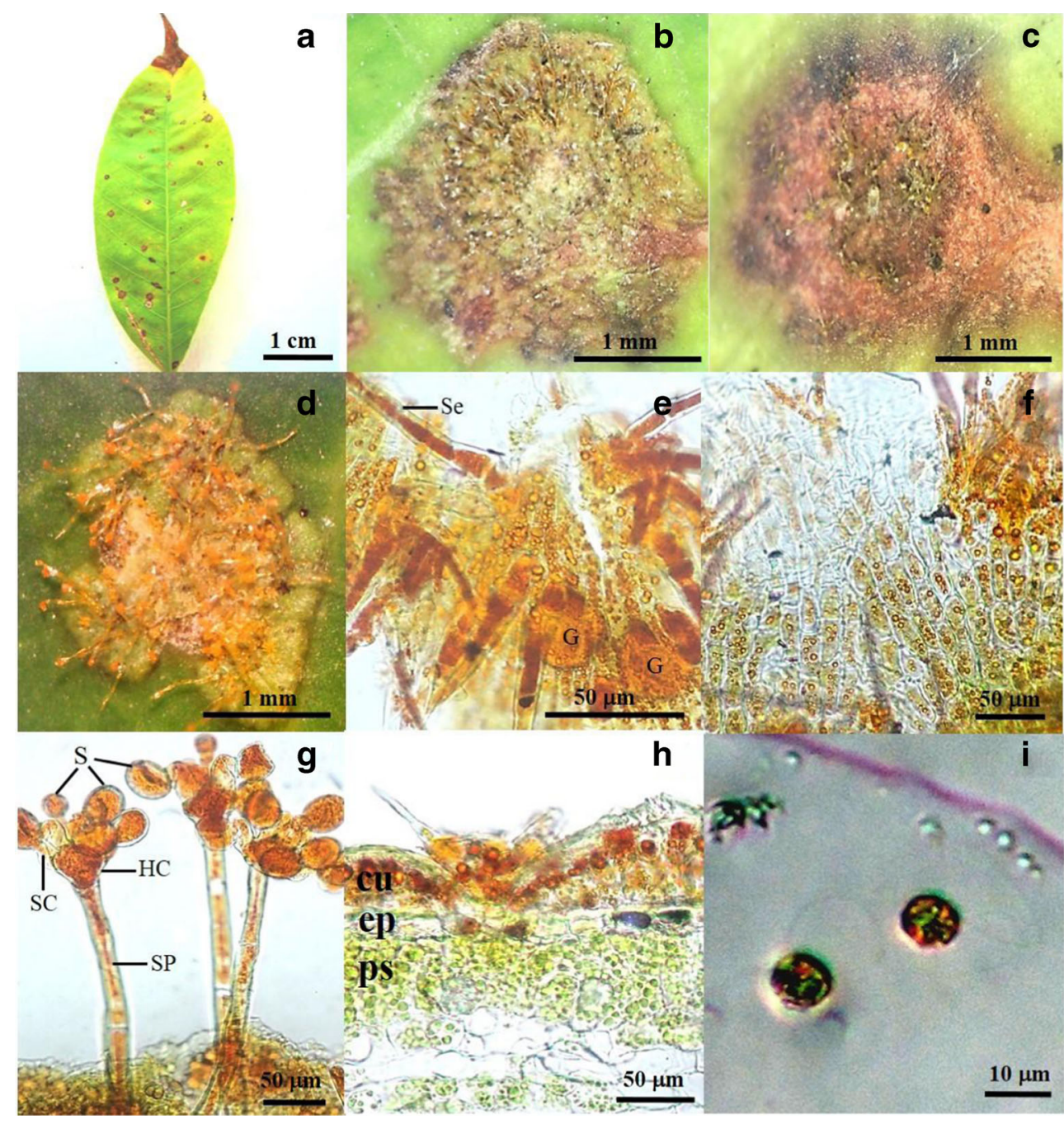

Cephaleuros virescens. To confirm the result from morphological characteristics, thallus of Cephaleuros was cultured on Bold's basal medium (Bischoff and Bold 1963; Andersen 2005) and subjected to DNA extraction and PCR amplification. A portion of $18 \mathrm{~S}$ rDNA was amplified by PNS1 (Hibbet 1996) and NS8 (White et al. 1990) primer pair. The PCR performed in $50 \mu \mathrm{l}$ reaction volume containing $10 \mathrm{pmol}$ of each primer, $2 \mathrm{x}$ DreamTaq Green PCR Master Mix (Thermo Scientific), and $50 \mathrm{ng}$ of template DNA. An initial denaturation step for $3 \mathrm{~min}$ at $95{ }^{\circ} \mathrm{C}$ was followed by 35 cycles of denaturation for $30 \mathrm{~s}$ at $95{ }^{\circ} \mathrm{C}$, annealing for $30 \mathrm{~s}$ at $50{ }^{\circ} \mathrm{C}$, and extension for $1 \mathrm{~min}$ at $72{ }^{\circ} \mathrm{C}$, with a final extension step of $10 \mathrm{~min}$ at $72{ }^{\circ} \mathrm{C}$. The PCR products were visualized by agarose gel electrophoresis. A PCR product band about 700 bases was observed from Cephaleuros sample. The partial 18S rDNA gene region then was bidirectionally sequenced at the Scientific Equipment Center Prince of Songkla Unversity,
Songkhla, Thailand. The nucleotide sequence analysis of the Cephaleuros 18S rRNA using BLAST search revealed that our partial sequence was 707 bases long. This nucleotide sequence was deposited in GenBank with accession number (AB984776) and compared to known Cephaleuros and other algal genus on the NCBI (the National Center for Biotechnology Information) databases. A $94 \%$ sequence identity confirmed it to be a member of the Cephaleuros group. Neighbor joining tree showing the genetic relationships of Thai Cephaleuros (PSU-PR01) was in the same clade with Cephaleuros genus, while well separated from the other genus (Fig. 2).

It has been previously reported that algal leaf spot disease on rubber plants in Sri Lanka is caused by Cephaleuros parasiticus (Karst) (Munasinghe 1961; Jayasinghe 2001). Furthermore, C. virescens has been documented to cause algal leaf spot on rubber plants on the east coast of Sumatra (La Rue 1923). Specimens of 


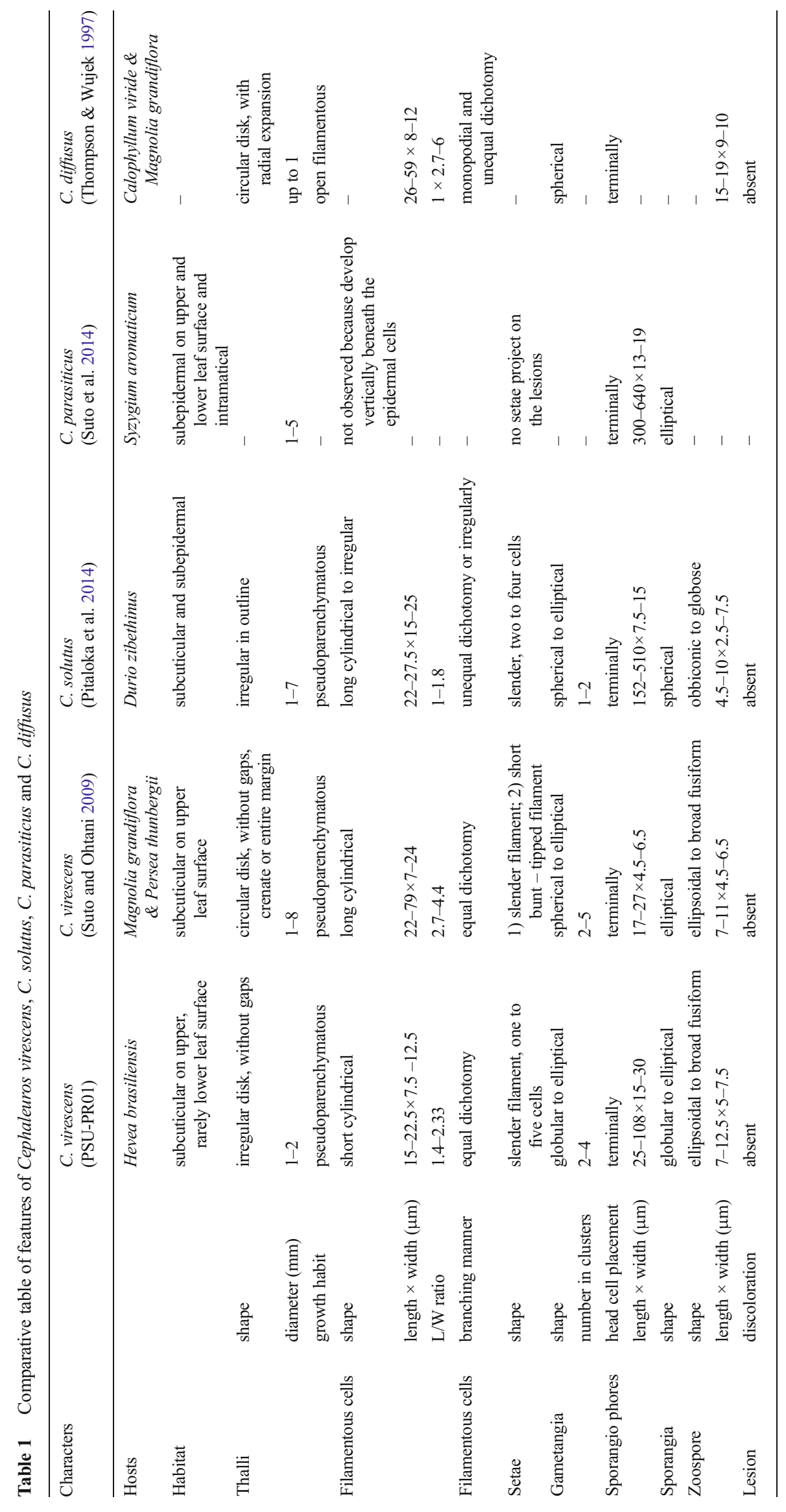


Fig. 2 Phylogenetic analysis of Thai Cephaleuros $(C$. virescens PSU-PR01) and other green alga (Trentepohliaceae, Chlorophyta) based on $18 \mathrm{~S}$ rDNA sequences. Bootstrap values are shown on the branches and the GenBank accession number are shown in parentheses. Bryopsis plumose represents the lack of similarity outside this group

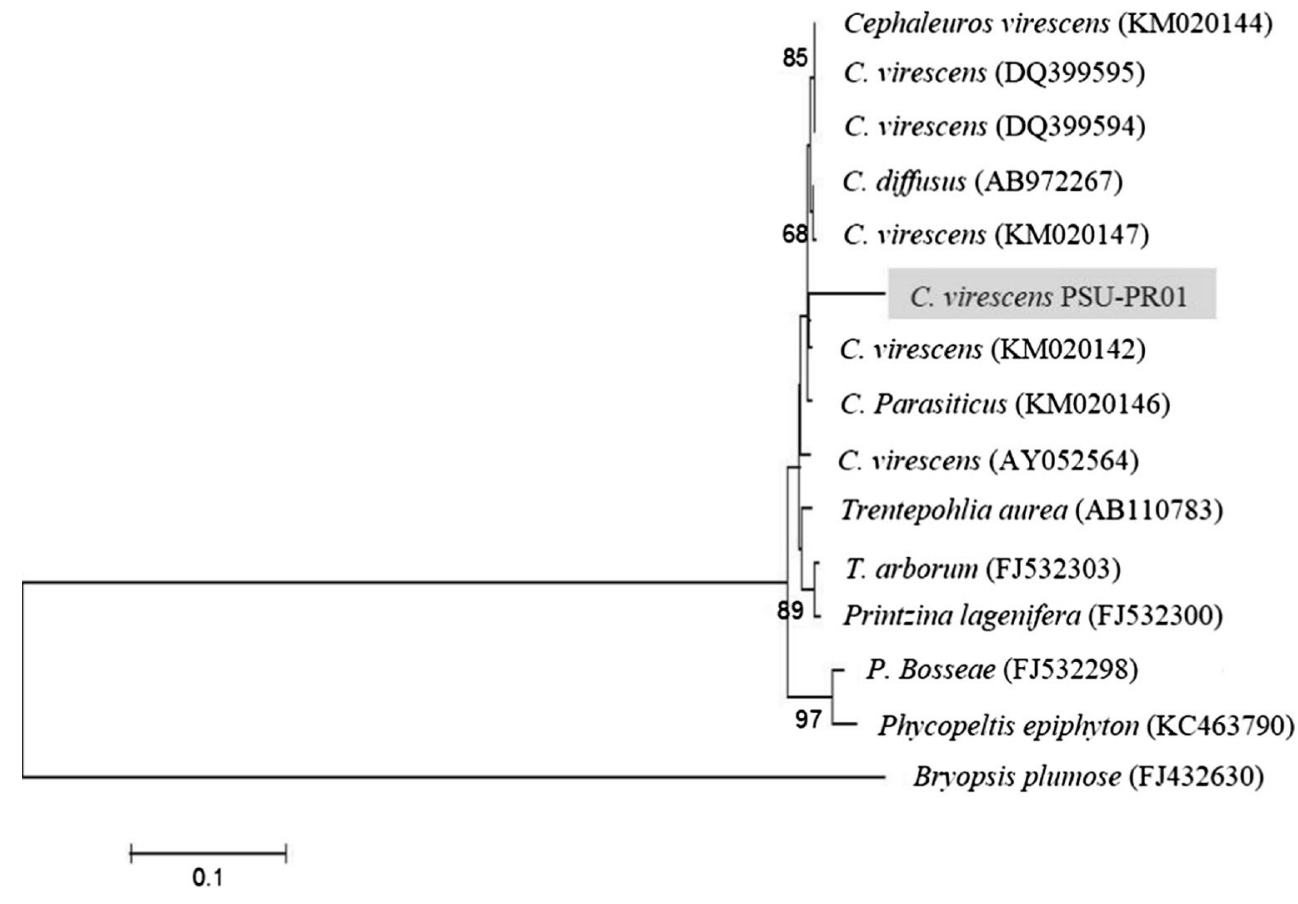

algae have also been deposited at the Culture Collection of the Pest Management Department, Faculty of Natural Resources, Prince of Songkla University, Thailand, for further studies.

Acknowledgments The authors would like to thank the Center of Excellence in Agricultural and Natural Resources Biotechnology (ANRB-CoE), Faculty of Natural Resources and Prince of Songkla University for funding and facilities. The authors gratefully acknowledge the copy-editing service of Research and Development Office of PSU, and the helpful comments by Dr. Alan Geater, we appreciate it.

\section{References}

Andersen RA (ed) (2005) Algal culturing techniques, Elsvier Academic Press, London, $578 \mathrm{p}$

Bischoff HW, Bold HC (1963) Phycological studies. IV. Some Soil Algae from Enhanted Rock and Related Algal Species. University of Texas Publication. 6318, 1-95 p

Chapman RL, Henk CH (1985) Observations on the habitat, morphology and ultrastructure of Cephaleuros parasticus (chlorophyta) and a comparison with C. virescens. J Phycol 21:513-522
Hibbet DS (1996) Phylogenetic evidence for horizontal transmission of group I introns in the nuclear ribosomal DNA of mushroom-forming fungi. Mol Biol Evol 13:903-917

Jayasinghe CK (2001) Check list of rubber pathogens in Sri Lanka. National Science Foundation, Colombo, $47 \mathrm{p}$

La Rue CD (1923) Two unreport parasite of Hevea brasiliensis. Paper from the Michigan Academy of Science, Arts and Letters, 69-71

Munasinghe HL (1961) Algal spot of Hevea leaves in Ceylon. Q J Rubber Res Inst Ceylon 37:49-50

Nelson SC (2008) Cephaleuros Species, the Plant Parasitic Green Algae. Plant Dis- PD-43

Pitaloka MK, Petcharat V, Sunpapao A (2014) Cephaleuros solutus Karsten, as a causal agent of durian (Durio zibethinus Murray) algal leaf spot disease in Thailand. Khon Khaen Agric J 42(supp13):644-648

Suto Y, Ohtani S (2009) Morphology and taxonomy of five Cephaleuros species (Trentepohliaceae, Chlorophyta) from Japan, including three new species. Phycologia 48(4):213-236

Suto Y, Ganesan EK, West JA (2014) Comparative observation on Cephaleuros parasiticus and C. virescens (Trentepohliaceae, Chlorophyta) from India. Algae 29(2):121-126

Thompson RH, Wujek DE (1997) Trentepohlliales Cephaleuros, Phycopeltis and Stomatochroon, morphology, taxonomy and ecology, 1st edn. Enfield Publishing and Distribution, United States of America, p 149

White TJ, Bruns TD, Lee S, Taylor J (1990) Amplification and direct sequencing of fungal ribosomal RNA genes for phylogenetics. In: Innis MA, Gelfand DH, Sninsky JJ, White TJ (eds) PCR protocols, a guide to methods and applications. Academic, San Diego, pp 315-322 